L. G. Petersen $\cdot$ J. Størling $\cdot$ P. Heding $\cdot$ S. Li $\cdot$

V. Berezin · J. Saldeen · N. Billestrup · E. Bock •

T. Mandrup-Poulsen

\title{
IL-1 $\beta$-induced pro-apoptotic signalling is facilitated by NCAM/FGF receptor signalling and inhibited by the C3d ligand in the INS-1E rat beta cell line
}

Received: 10 January 2006 / Accepted: 10 March 2006 / Published online: 23 May 2006

C) Springer-Verlag 2006

\begin{abstract}
Aims/hypothesis: IL-1 $\beta$ released from immune cells induces beta cell pro-apoptotic signalling via mitogen-activated protein kinases (MAPKs) and nuclear factor- $\mathrm{kB}$ (NF-kB). In neurons, the neural cell adhesion molecule (NCAM) signals to several elements involved in IL-1 $\beta$-induced pro-apoptotic signalling in beta cells. Pancreatic beta cells express NCAM, but its biological effects in these cells are unclear. The aim of this study was to investigate whether there is cross-talk between NCAM signalling and cytokine-induced pro-apoptotic signalling. Materials and methods: Western blotting was used to investigate levels of NCAM and inducible nitric oxide synthase, phosphorylation of $\mathrm{Src}$ and MAPKs, and cleavage of caspase-3. MAPK activity was investigated with an in vitro kinase assay. Apoptosis was detected by cleaved caspase-3 and a Cell Death Detection ELISA ${ }^{\text {plus }}$ assay. NCAM-induced fibroblast growth factor receptor (FGFR) activation was investigated in $\mathrm{NCAM}^{-1-}$ Trex293 cells where FGFR phosphorylation was measured by Western blotting after NCAM transfection. Results: Pre-
\end{abstract}

L. G. Petersen · J. Størling · P. Heding · N. Billestrup ·

T. Mandrup-Poulsen $(\bowtie)$

Steno Diabetes Center,

Niels Steensens Vej 2,

2820 Gentofte, Denmark

e-mail: TMPo@Steno.dk

Tel.: +45-44439101

Fax: $+45-44438232$

S. Li · V. Berezin · E. Bock

Protein Laboratory,

Institute of Molecular Pathology,

Copenhagen N, Denmark

\section{J. Saldeen}

Department of Laboratory Medicine,

Division of Clinical Chemistry,

Karolinska University Hospital,

Huddinge, Sweden

T. Mandrup-Poulsen

Department of Molecular Medicine,

Karolinska Institute,

Stockholm, Sweden exposure of INS-1E cells to the FGFR-inhibitor SU5402, but not to the Src-inhibitor PP2, dose-dependently inhibited IL-1 $\beta$-mediated MAPK activity. A synthetic peptide, C3d, reported to bind NCAM, did not activate MAPK or Akt as reported in neurons but inhibited IL-1 $\beta$ induced MAPK activity, thereby mimicking the effect of SU5402. Furthermore, C3d inhibited NCAM-induced FGFR phosphorylation and apoptosis induced by IL- $1 \beta$ plus IFN- $\gamma$, but did not affect IL- $1 \beta$-induced NF-kB signalling. Conclusions/interpretation: We suggest that NCAM signalling through FGFR is required for efficient IL-1 $\beta$ pro-apoptotic signalling by facilitating IL- $1 \beta$ induced MAPK activation downstream of the NF-KBMAPK branching point. Further, these data identify a novel function of $\mathrm{C} 3 \mathrm{~d}$ as an inhibitor of NCAM-induced FGFR activity and of IL- $1 \beta$-induced MAPK activation in beta cells.

Keywords Apoptosis - C3d · INS-1E - IL-1 $\beta$.

Mitogen-activated protein kinase $\cdot$ Neural cell adhesion molecule Pancreatic beta cells

\begin{abstract}
Abbreviations ERK: extracellular signal-regulated kinase - FGF: fibroblast growth factor - FGFR: FGF receptor - GST: glutathione-S-transferase - HRP: horseradish peroxidase $\cdot$ Hsp: heat-shock protein - IKB: inhibitor- $\mathrm{kB} \cdot \mathrm{iNOS}$ : inducible nitrogen-oxide synthase JNK: c-Jun N-terminal kinase $\cdot$ MAPK: mitogen-activated protein kinase $\cdot$ MAPKAPKII: MAPK-activated protein kinase II - MEK: MAPK/ERK kinase · NCAM: neural cell adhesion molecule $\cdot \mathrm{NF}-\mathrm{kB}$ : nuclear factor- $\mathrm{kB} \cdot \mathrm{p} 38$ : $\mathrm{p} 38$ MAPK $\cdot$ PKC: protein kinase C $\cdot$ PI3K:

phosphatidylinositol 3-kinase
\end{abstract}

\section{Introduction}

IL- $1 \beta$ in combination with IFN- $\gamma$ and/or TNF- $\alpha$ is cytotoxic to beta cells and believed to play an important role in the beta cell destruction that leads to type 1 diabetes $[1,2]$. The predominant mode of destruction caused by 
these cytokines in human primary beta cells is apoptosis [3, 4]. The pro-apoptotic signalling pathways induced by IL$1 \beta$ involve the family of mitogen-activated protein kinases (MAPK) as well as the nuclear factor- $\mathrm{KB}(\mathrm{NF}-\mathrm{kB})$ and protein kinase $\mathrm{C}$ (PKC) pathways [2]. The MAPK family consists of extracellular signal-regulated kinase (ERK), c-Jun N-terminal kinase (JNK), and p38 MAPK (p38), all of which are activated after phosphorylation by IL- $1 \beta$ in beta cells [5]. JNK especially is in focus because inhibition of this MAPK blocks IL-1 $\beta$-mediated beta cell death in vitro [6].

In neurons, which share several phenotypic characteristics with beta cells [7], the neural cell adhesion molecule (NCAM) has been studied intensively [8]. NCAMmediated adhesion plays a critical role in the nervous system during development, neurite outgrowth, neuronal differentiation, and plasticity $[9,10]$. Alternative splicing results in three isoforms: one linked to the cell membrane via a glycosylphosphatidylinositol anchor of $120 \mathrm{kDa}$ and two transmembrane isoforms of $140 \mathrm{kDa}$ and $180 \mathrm{kDa}$. The precise functions of the three isoforms are not completely understood [11].

In addition to its role in cell adhesion, NCAM elicits intracellular signalling after homo- or heterophilic interaction. Structural evidence suggests that NCAM molecules form cis dimers in the cell membrane and these cis dimers mediate trans interactions between cells via formation of two-dimensional zippers [12, 13]. In neurons the extracellular part of NCAM has been shown to bind and mediate phosphorylation/activation of the fibroblast growth factor receptor (FGFR) $[14,15]$. This initiates signalling downstream FGFR leading to activation of PKC and an increase in the intracellular concentrations of arachidonic acid and $\mathrm{Ca}^{2+}[16]$. In addition, the intracellular part of NCAM mediates the activation of NF-KB [17] and of Akt via phosphatidylinositol 3-kinase (PI3K) [18]. The NCAM140 isoform further interacts with the Src-homology kinase Fyn leading to Fak-recruitment and activation of the RasRaf-MEK-ERK pathway [19]. By means of combinatorial chemistry, a synthetic peptide termed $\mathrm{C} 3 \mathrm{~d}$ has been shown to bind NCAM [20]. C3d disrupts NCAM-mediated cell adhesion in vitro and induces intracellular signalling and responses similar to that activated by homophilic NCAM binding in neurons [21-24]. C3d has recently been reported to protect neurons against apoptosis via PI3K and Akt activation [18].

Transformed beta cell lines have been reported to express mainly NCAM-140 and in some studies also NCAM-180 though to a minor degree [7, 25-29]. It is unclear which NCAM isoforms are expressed in primary beta cells. In some studies mainly the NCAM-140 isoform is reported [7, 25, 28, 29] whereas others report that mainly NCAM-120 is expressed in adult islets and expression of NCAM-140 is found only during development and in tumours $[26,27]$. In beta cells, NCAM has been suggested to be involved in the organisation of biosociology in the islets of Langerhans [26], in beta cell functional activity measured as insulin release [30], and also in natural killer T cell-induced beta cell death [31]. Furthermore, in mouse pancreatic tumour beta cells,
NCAM has been shown to activate a Src-kinase and to bind and activate FGFR [32].

The effect of NCAM signalling on IL- $1 \beta$-induced MAPK signalling and apoptosis in beta cells has not been investigated previously. Since several of the abovementioned components activated by NCAM signalling in neurons are involved in cytokine-induced apoptosis in beta cells (i.e. p38 [33], ERK [34], $\mathrm{Ca}^{2+}$ [35], arachidonic acid [36], PKC [37], NF-kB [38] and Akt [39]), we examined whether there is cross-talk between NCAM signalling and IL-1 $\beta$-induced pro-apoptotic signalling via MAPK in beta cells. We report that NCAM/FGFR signalling facilitates IL-1 $\beta$-induced MAPK activity in the beta cell line INS-1E and in intact islets. By inhibiting NCAM-mediated FGFR signalling we were further able to inhibit apoptosis induced by IL- $1 \beta$ plus IFN- $\gamma$ in INS cells.

\section{Materials and methods}

\section{Reagents}

Recombinant mouse IL-1 $\beta$ was obtained from BD Bioscience PharMingen (San Diego, CA, USA), and recombinant rat IFN- $\gamma$ and recombinant human fibroblast growth factor (FGF) 1 were supplied by R\&D Systems (Minneapolis, MN, USA).

FGFR1 inhibitor SU5402 $\left(\mathrm{IC}_{50}=10-20 \mu \mathrm{mol} / \mathrm{l}\right)$ and $\mathrm{Src}$ inhibitor PP2 $\left(\mathrm{IC}_{50}=5 \mathrm{nmol} / \mathrm{l}\right)$ were purchased from Merck KGaA (Darmstadt, Germany).

C3d, a dendrimer of four peptide monomers (ASKKPKRNIKA) coupled to a lysine backbone, and two mutated C3d peptides - C3d 2ala (ASKKPAANIKA) and $\mathrm{C} 3 \mathrm{~d}$ 3ala (ASKAPAANIKA) - were produced and characterised as described previously [20]. The stated concentrations of peptides represent the concentrations of the peptide monomers (i.e. four times higher than the concentration of the dendrimeric peptides).

Antibodies to phospho-SAPK/JNK; total-SAPK/JNK; phospho-MAPK p42/44 (ERK); total MAPK p42/44; phospho p38; total p38; phospho-Src family (Tyr416); cleaved caspase-3 (Asp175); and phospho Akt (Ser473) were obtained from Cell Signaling (Cambridge, MA, USA), and raised in rabbits. Agarose-coupled antiphosphotyrosine antibodies (4G10-AC) were from Upstate Biotechnologies (Lake Placid, NY, USA). Rabbit antibodies against the recombinant StrepII tag were from IBA Biotech (Gottingen, Germany). Horseradish peroxidase (HRP)-conjugated Anti-Tubulin was supplied by Santa Cruz Biotechnology (San Francisco, CA, USA). AntiNCAM was obtained as described elsewhere [40]. Antiinhibitor- $k \mathrm{~B} \alpha(\mathrm{I} \kappa \mathrm{B} \alpha)$ was from Active Motif (San Francisco, CA, USA) and was raised in mouse. Antiinducible nitric oxide synthase (iNOS) was from BD Bioscience and was raised in rabbit. As secondary antibodies, HRP-anti-rabbit was purchased from Cell Signaling, HRP-anti-Mouse was from Oncogene (Cambridge, MA, USA), and swine HRP-anti-rabbit was obtained from DakoCytomation (Glostrup, Denmark). 
Rat islet isolation and pre-culture

Rat islet isolation and pre-culture were performed as described previously [5]. Pancreata from 5- to 7-day-old Wistar Furth rats (Taconic, Rye, Denmark) were collagenase-digested and islets were isolated. One hundred and fifty islets were pre-cultured for 5-7 days at $37^{\circ} \mathrm{C}$ in humidified air in complete RPMI-1640 medium (RPMI1640 with glutamax [Invitrogen, Carlsbad, CA, USA], $50 \mu \mathrm{mol} / \mathrm{l} \beta$-mercaptoethanol, $100 \mathrm{U} / \mathrm{ml}$ penicillin, and $100 \mu \mathrm{g} / \mathrm{ml}$ streptomycin), supplemented with 10\% FCS.

\section{Neurons}

Hippocampal neurons were isolated from Wistar rat foetuses (Charles River, Sulzfeld, Germany) at embryonic days 18-19 as described elsewhere [24]. After isolation, neurons were cultured on poly-L-lysine-coated dishes for $24 \mathrm{~h}$ at $37^{\circ} \mathrm{C}$ in a humidified atmosphere of $5 \% \mathrm{CO}_{2}$ in neurobasal medium containing B27 supplement (all from Invitrogen).

Insulinoma cell culture

All experiments with clonal rat beta cells were performed with INS-1E except for that illustrated in Fig. 9a, which was performed with INS-1. Both INS sub-clones were cultured in complete RPMI-1640 medium supplemented with $10 \% \mathrm{FCS}$, at $37^{\circ} \mathrm{C}$ in a humidified atmosphere containing $5 \% \mathrm{CO}_{2}$. When confluent, cells were trypsinised and seeded for culture and experiments. In experiments with low serum concentrations $(0.5 \%)$, cells were seeded in medium with $10 \%$ serum and allowed to adhere overnight before the medium was changed to medium containing $0.5 \%$ serum and then left overnight again before stimulation.

Islet, neuron and INS-1 cell lysis and measurement of protein concentration

After exposure, cells were lysed for $30 \mathrm{~min}$ as described by Larsen et al. [5]. The protein concentrations were measured by the Bradford method according to the manufacturer's instructions (BioRad, Hercules, CA, USA).

In vitro kinase assay

In vitro kinase assay was performed as described previously [5]. Whole-cell lysates were incubated with a reaction buffer containing glutathione- $S$-transferase (GST)Elk1, GST-c-Jun, and GST-heat-shock protein (Hsp)25 (substrates for ERK, JNK, and the p38-activated kinase MAPKAPKII, respectively) and $\left[\gamma^{-32}\right.$ P $]$ ATP for $30 \mathrm{~min}$ at $30^{\circ} \mathrm{C}$. NuPAGE was performed as described by the manufacturer (Invitrogen), the gels were dried and placed on a storage phosphor screen. ${ }^{32} \mathrm{P}$-labelled proteins were visualised by autoradiography and quantified by PhosphorImager analysis (Amersham Pharmacia, San Francisco, CA, USA) according to the manufacturer's instructions.

\section{Western blotting}

Western Blotting was performed as described by the manufacturer (Invitrogen). The protein of interest was detected by a chemiluminescence detection system (LumiGLO; Cell Signaling) and visualised using an imaging system (Las3000; Fuji Film, Tokyo, Japan) according to the manufacturer's instructions. For detection of NCAM a modified protocol was used: after electroblotting, membranes were blocked in 2\% Tween-20 in PBS for 4 min and washed once in washing buffer $(0.05 \mathrm{~mol} / 1$ Tris- $\mathrm{HCl}$, $1.5 \mathrm{~mol} / \mathrm{l} \mathrm{NaCl}$, and $0.5 \%$ Tween-20; $\mathrm{pH} \mathrm{10.2)} \mathrm{for} 5 \mathrm{~min}$ before NCAM antibody diluted in washing buffer was added overnight. Membranes were then washed for $5 \mathrm{~min}$ three times in washing buffer, secondary HRP-conjugated antibody was added, and proteins were visualised by chemiluminescence.

\section{Luciferase reporter assay}

Transient transfection with plasmid DNAs (pRenilla $0.1 \mu \mathrm{g} /$ well [Promega, Madison, WI, USA] and pNF-kBluc $0.4 \mu \mathrm{g} /$ well [BD Bioscience]) was performed with lipofectamine as described by the manufacturer (Invitrogen). One day after transfection, cells were stimulated and lysed (Promega) before the luciferase activity was assayed as a measure of NF- $\mathrm{kB}$ promoter activity with the Dual-Luciferase Reporter Assay System (Promega) using a Luminometer (Berthold Technologies, Bad Wildbad, Germany), according to the manufacturer's instructions. NF-KB promoter activity was normalised to the activity of coexpressed Renilla luciferase.

Cell death detection ELISA ${ }^{\text {PLUS }}$ assay

Histone/DNA complexes released from the nucleus to the cytoplasm were measured according to the manufacturer's instructions (Roche, Basel, Switzerland). In short, cells were lysed and incubated with anti-DNA-peroxidase and anti-histone-biotin and transferred to streptavidin-coated wells. After addition of peroxidase substrate (ABTS), the absorbance was measured.

\section{Determination of phosphorylation of FGFR1}

Trex293 cells (Invitrogen) were stably transfected with human FGFR1, splice variant IIIc, with a C-terminal Strep II tag (IBA Biotech). The cells were maintained in Dulbecco's modified Eagle's medium with $200 \mu \mathrm{g} / \mathrm{ml}$ hygromycin (Invitrogen), 10\% FCS, 1\% glutamax, $100 \mathrm{U} / \mathrm{ml}$ 
penicillin, $100 \mu \mathrm{g} / \mathrm{ml}$ streptomycin (all from Gibco BRL, Paisley, UK). Cells were starved overnight in medium without serum before being treated with $\mathrm{C} 3 \mathrm{~d}$. Cells were lysed in lysis buffer containing 1\% Nonidet P-40 (SigmaAldrich, Copenhagen, Denmark), complete protease inhibitors (Roche) (1:50), phosphatase inhibitors (Calbiochem inhibitor cocktail III) $(1: 100)$ in PBS. Protein concentration was determined using the bicinchoninic acid assay (Pierce, Rockville, IL, USA). From each lysate $500 \mu \mathrm{g}$ protein was incubated with $15 \mu \mathrm{l}$ agarose-coupled anti-phosphotyrosine antibodies for $6 \mathrm{~h}$ at $4^{\circ} \mathrm{C}$. The bound proteins were washed and eluted with $180 \mathrm{mmol} / \mathrm{l}$ phenylphosphate (Sigma-Aldrich). Purified proteins ( $25 \mu \mathrm{l}$ from each sample) were separated by SDS-PAGE and transferred to a polyvinylidene fluoride membrane (Millipore, Bedford, MA, USA). Immunoblotting was performed using antibodies against the recombinant StrepII tag (IBA Biotech), developed with SuperSignal West Dura extended duration substrate (Pierce), and visualised and quantified using the SynGene Gene Tool image analysis software (Synoptics, Cambridge, UK).

Transfection of Trex293 cells with NCAM-140

Trex293 cells were transfected with the pcDNA3.1 vector (Invitrogen) with an insert coding for rat NCAM-140 using Targetfect F2 reagent (Targetsys, San Diego, CA, USA) according to manufacturer's procedure.

\section{Statistical analysis}

Results are presented as means \pm SEM. Western blot quantifications were adjusted for loading variations measured by blotting against tubulin. Where appropriate, statistical significances were determined by the Student's paired $t$ test with $p<0.05$ as the level of significance.

\section{Results}

INS-1E cells and rat islets express NCAM-140 and the NCAM binding peptide, C3d, activates NCAM signalling

NCAM expression in INS-1E cells and in rat islets was investigated by Western blotting. Freshly prepared rat brain extracts were used as control tissue expressing all three NCAM isoforms. We found that INS-1E cells and islets from neonatal rats expressed NCAM-140 (Fig. 1a). NCAM signals through a Src kinase in both neurons and beta cells $[32,41]$. In neurons the NCAM-binding peptide C3d activates NCAM signalling [20] and we wished to examine in beta cells the effect of C3d on Src kinase activity. As seen in Fig. 1b, we found that exposure to $\mathrm{C} 3 \mathrm{~d}$ increased the phosphorylation of a Src kinase suggesting that $\mathrm{C} 3 \mathrm{~d}$ is also an agonist of NCAM signalling in beta cells.

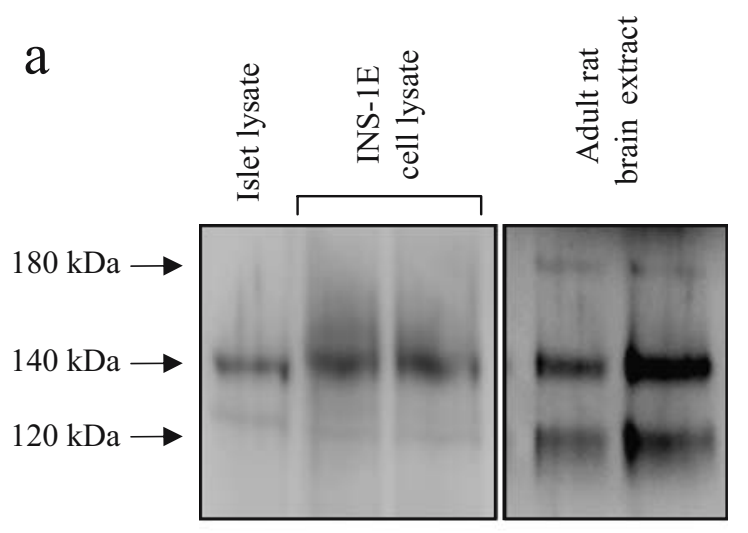

b

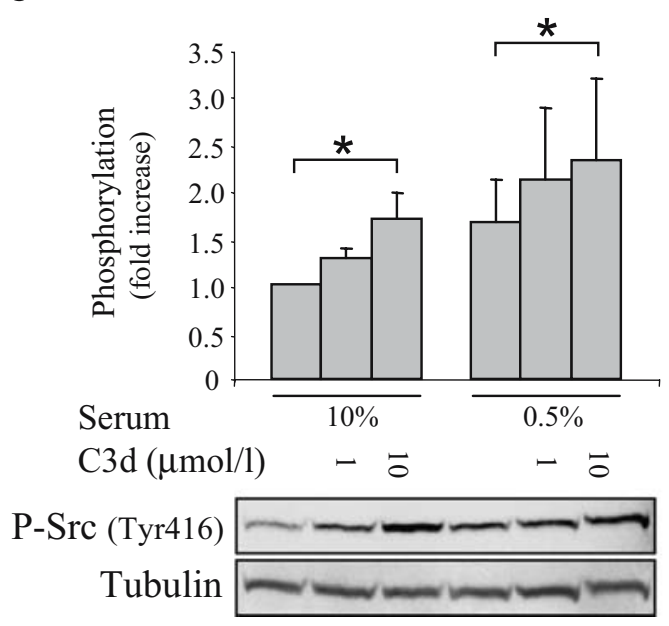

Fig. 1 Rat islets and INS-1E cells express NCAM-140, and C3d induces phosphorylation of a Src-kinase. a Whole-cell lysates from INS-1E cells $(n=2)$ and islets $(n=3$; a representative blot is shown) were subjected to western blotting using an NCAM-specific antibody. Freshly prepared lysates of adult rat brain extracts $(n=2)$ expressing the three NCAM isoforms of 120,140 , and $180 \mathrm{kDa}$, were used as a positive control. b Cells were cultured in 0.5 or $10 \%$ serum before exposure to $\mathrm{C} 3 \mathrm{~d}$ ( 1 or $10 \mu \mathrm{mol} / \mathrm{l})$ for $30 \mathrm{~min}$. P-Src was assessed by western blotting, $n=6$. Anti-tubulin was used as a loading control. ${ }^{*} p<0.05$

Inhibition of FGFR, but not the Src family of tyrosine kinases, decreases IL- $1 \beta$-induced activity of the MAPKs

We investigated the effect of two different inhibitors of NCAM/FGFR signalling: SU5402, an inhibitor of FGFR, and PP2, an inhibitor of the Src family of tyrosine kinases. INS-1E cells were pre-exposed to PP2 or SU5402 before exposure to IL-1 $\beta$ and then analysed for MAPK activities. IL-1 $\beta$-induced phosphorylation of the MAPK substrates Elk-1 (ERK), c-Jun (JNK), and Hsp25 (p38) was not affected by PP2 (Fig. 2a-c). In contrast, SU5402 dosedependently decreased IL-1 $\beta$-induced phosphorylation of the substrates (Fig. 2d-f). These findings suggest that signalling through FGFR, but not through a Src kinase, is necessary for efficient IL-1 $\beta$ signalling to MAPK. 

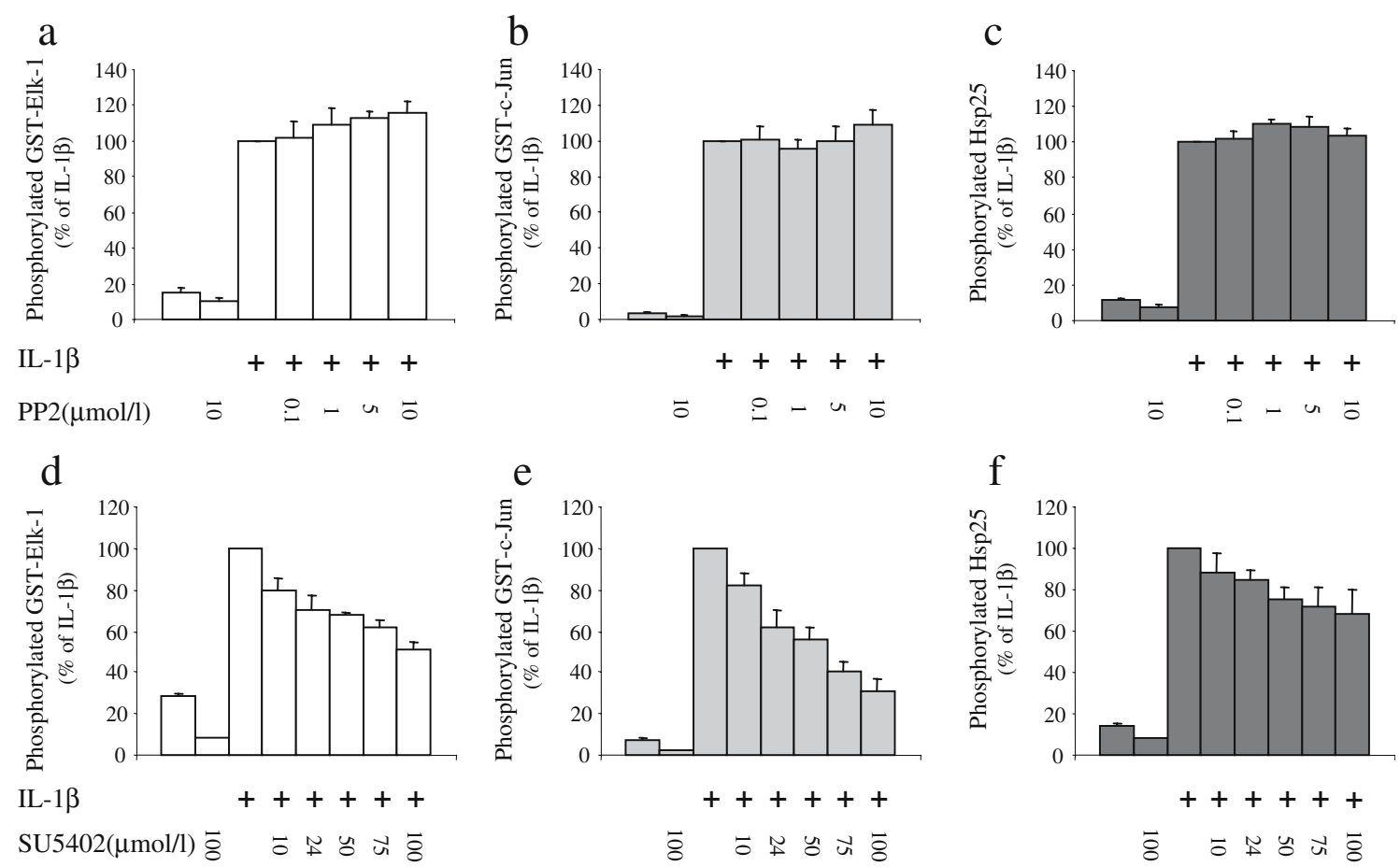

Fig. 2 Inhibition of FGFR, but not Src, decreases IL- $1 \beta$-induced MAPK activity. Cells were pre-exposed to the Src inhibitor PP2 $(0.1-10 \mu \mathrm{mol} / 1) \quad(\mathbf{a}-\mathbf{c})$ or the FGFR inhibitor SU5402 (10$100 \mu \mathrm{mol} / \mathrm{l})(\mathbf{d}-\mathbf{f})$ for $1 \mathrm{~h}$ before exposure to IL-1 $\beta(160 \mathrm{pg} / \mathrm{ml})$

for $20 \mathrm{~min}$. MAPK activities were assessed by in vitro kinase assay. Bars represent means+SEM from five independent experiments $(\mathbf{a}-\mathbf{c})$ or four to six independent experiments (except for SU $100 \mu \mathrm{mol} / 1, n=2)(\mathbf{d}-\mathbf{f})$

C3d does not activate MAPK or Akt, but inhibits IL$1 \beta$-mediated MAPK activity/phosphorylation in beta cells

To investigate in beta cells the effects of C3d on Akt and MAPK activities/phosphorylation and whether C3d modulated IL-1 $\beta$ signalling, we pre-exposed cells to $\mathrm{C} 3 \mathrm{~d}$ before exposure to IL-1 $\beta$ and measured Akt phosphorylation and MAPK activities. In contrast to findings in neurons, C3d had no agonistic effect on either Akt phosphorylation (Fig. 3a) or MAPK activities (Fig. 3b-d) in INS-1E cells. Interestingly, $\mathrm{C} 3 \mathrm{~d}$ inhibited IL-1 $\beta$-mediated MAPK activation in INS-1E cells (Fig. 3b-d) and phosphorylation in islets (Fig. 3e-g). This indicates that C3d affects NCAM signalling differently in beta cells compared to neurons. As the SU5402 inhibitor, C3d had a negative effect on IL-1 $\beta$ induced MAPK activities in INS-1E cells and MAPK phosphorylation in islets, suggesting that $\mathrm{C} 3 \mathrm{~d}$ is an antagonist of NCAM-mediated FGFR but not of Src signalling in beta cells.

We next wished to investigate whether the non-agonistic effect of C3d on ERK activity in beta cells was a consequence of that $\mathrm{C} 3 \mathrm{~d}$ being presented to NCAM after NCAM trans dimers were formed and NCAM was activated. This was investigated by adding C3d to cells seeded at low density to avoid contact with neighbouring cells and by pre-coating wells with $\mathrm{C} 3 \mathrm{~d}$ before cells were seeded. We found no agonistic effect of C3d on any of the
MAPK activities, while soluble, but not pre-coated, C3d inhibited IL-1 $\beta$-induced MAPK activity (data not shown). Furthermore, we investigated if $\mathrm{C} 3 \mathrm{~d}$ could enhance ERK activity at lower/higher concentrations $(0.5-50 \mu \mathrm{mol} / \mathrm{l})$, after different periods of exposure (15-60 min), or when added to serum-starved cells $(0.5 \%$ FCS $)$ to eliminate FGF in the medium. In none of these experiments was there an agonistic effect of C3d on MAPK activities (data not shown). Together these findings support the theory that C3d does not activate MAPK via NCAM in INS-1E cells and that the inhibitory effect of $\mathrm{C} 3 \mathrm{~d}$ on IL- $1 \beta$ signalling may be caused by its interaction with active NCAM dimers and thereby inhibition of NCAM-induced FGFR activation since only soluble but not matrix-bound $\mathrm{C} 3 \mathrm{~d}$ had an effect.

\section{C3d, but not IL-1 $\beta$, activates the MAPKs in neurons}

To verify the agonistic effect of C3d on ERK activity in neurons and to investigate the effect of IL- $1 \beta$ on neuronal MAPK activities we exposed primary hippocampal neurons from rat foetuses to $\mathrm{C} 3 \mathrm{~d}$ and $\mathrm{IL}-1 \beta$. As seen in Fig. 4a-c, not only ERK activity but also p38 and JNK activities were increased by C3d whereas IL-1 $\beta$ had no effect. This indicates that there are cell-specific differences in the responses of neurons and beta cells to both $\mathrm{C} 3 \mathrm{~d}$ and IL- $1 \beta$. 


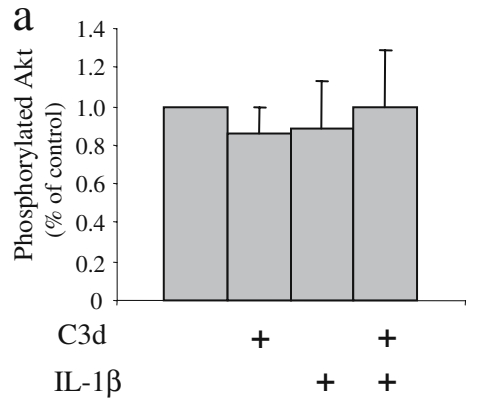

$\begin{aligned} \text { P-Akt } & \square-\square \\ \text { Tubulin } & \square-\square\end{aligned}$

b

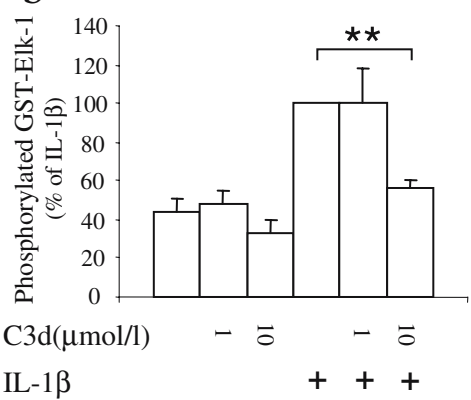

e

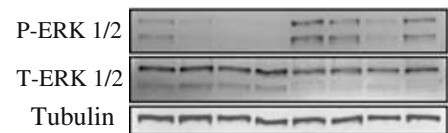

IL-1 $\beta$

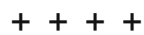

$\operatorname{SU} 5402(\mu \mathrm{mol} / 1)$ :ै

$\mathrm{C} 3 \mathrm{~d}(\mu \mathrm{mol} / \mathrm{l})$ के भू के भू

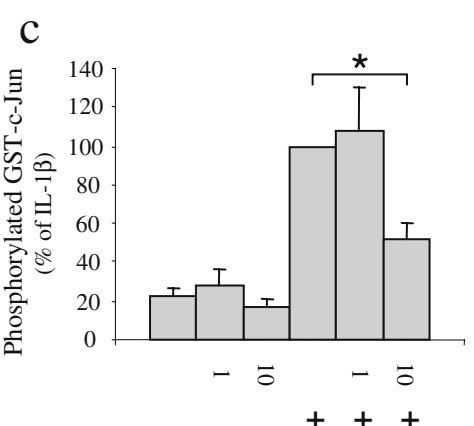

f

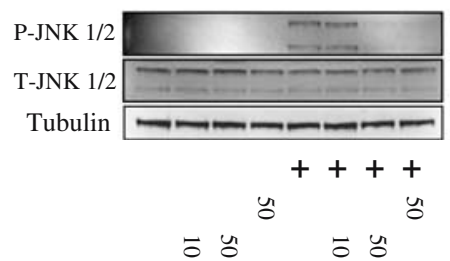

d

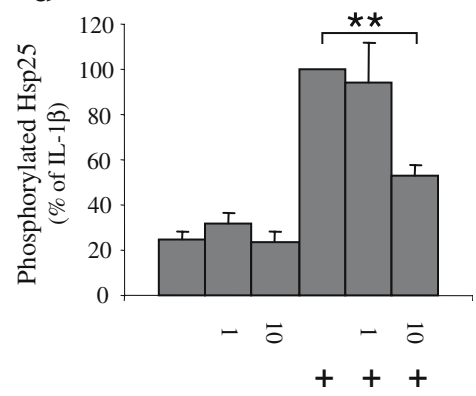

g

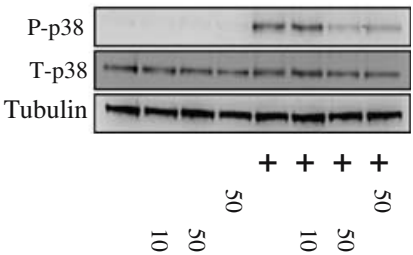

Fig. $3 \mathrm{C} 3 \mathrm{~d}$ has no effect on Akt phosphorylation or MAPK activity/ phosphorylation in beta cells but decreases IL-1 $\beta$-induced MAPK activity/phosphorylation. Cells $(\mathbf{a}-\mathbf{d})$ or rat islets $(\mathbf{e}-\mathbf{g})$ were preexposed to $\mathrm{C} 3 \mathrm{~d}(1,10$ or $50 \mu \mathrm{mol} / \mathrm{l})$ for $30 \mathrm{~min}$ or SU5402 $(50 \mu \mathrm{mol} / \mathrm{l})$ for $1 \mathrm{~h}$ before exposure to IL-1 $\beta(160 \mathrm{pg} / \mathrm{ml})$ for 20 min. P-Akt was assessed by western blotting (a), and MAPK activities were assessed by in vitro kinase assay (b-d). Bars represent means+SEM from four (a) or five (b-d) independent experiments. ${ }^{*} p<0.05, * * p<0.01$. MAPK phosphorylation in islets was measured by western blotting using phospho-specific antibodies $(n=2)$ and representative blots are shown $(\mathbf{e}-\mathbf{g})$. Anti-tubulin was used as a loading control a

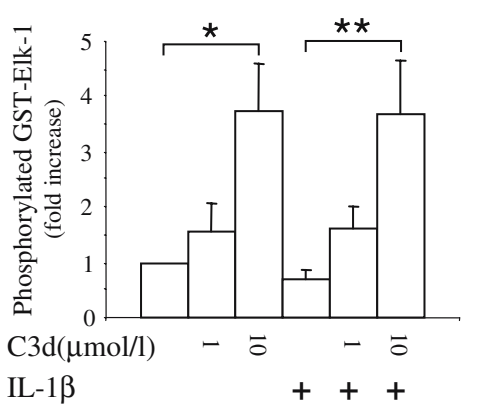

$\mathrm{b}$

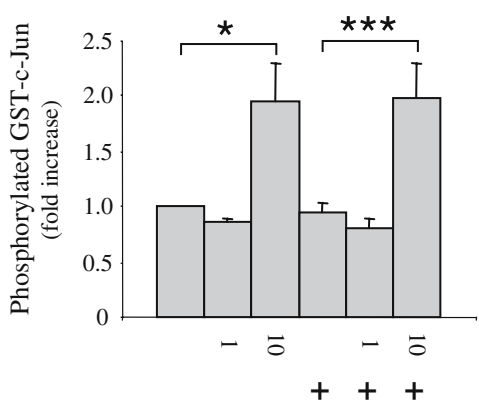

c

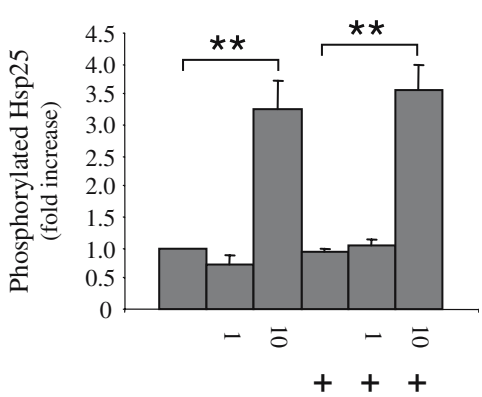

Fig. $4 \mathrm{C} 3 \mathrm{~d}$, but not IL-1 $\beta$, increases MAPK activity in neurons. Neurons were pre-exposed to $\mathrm{C} 3 \mathrm{~d}(1$ or $10 \mu \mathrm{mol} / \mathrm{l})$ for $30 \mathrm{~min}$ before exposure to IL-1 $\beta(160 \mathrm{pg} / \mathrm{ml})$ for $20 \mathrm{~min}$. MAPK activities were assessed by in vitro kinase assay and means + SEM of four experiments are shown. ${ }^{*} p<0.05,{ }^{* *} p<0.01, * * * p<0.001$ 


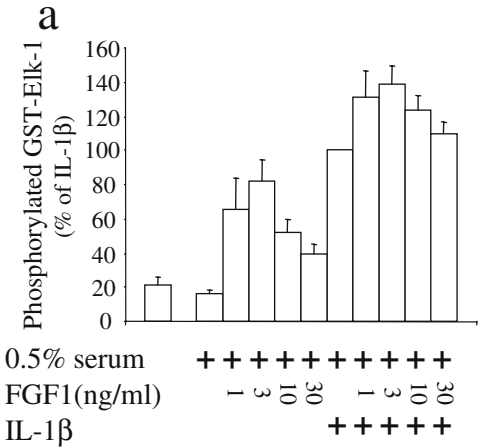

Fig. 5 FGF1 induces ERK, but not JNK or p38, activity. Cells were serum starved $(0.5 \%$ serum $)$ or not $(10 \%$ serum $)$ before exposure to FGF1 $(1-30 \mathrm{ng} / \mathrm{ml})$ for $1 \mathrm{~h}$ and to IL-1 $\beta(160 \mathrm{pg} / \mathrm{ml})$ for $20 \mathrm{~min}$.

Exposure to FGF1 increases both basal and IL-1 $\beta$ mediated ERK activity without affecting activities of JNK and p38

To address whether the observed effect of C3d on IL-1 $\beta$ mediated MAPK activities is independent of NCAM and restricted to the FGFR, we exposed cells to FGF1 to see the effect of NCAM-independent activation of the FGFR on basal and IL-1 $\beta$-induced MAPK activities. Serum-starved cells were pre-exposed to FGF1 for $1 \mathrm{~h}$ before exposure to IL-1 $\beta$ for 20 min. As seen in Fig. 5a, FGF1 activated ERK as expected and augmented IL-1 $\beta$-mediated ERK activity with a maximum effect at $3 \mathrm{ng} / \mathrm{ml}$. There was no effect on basal or IL-1 $\beta$-mediated JNK and p38 activities (Fig. 5b,c),

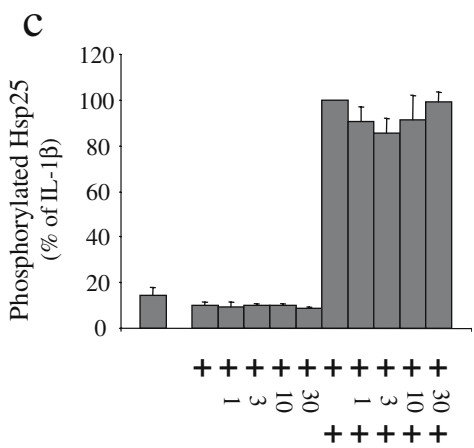

MAPK activities were assessed by in vitro kinase assay and means + SEM of three experiments are shown

indicating that FGFR signalling does not interact with the JNK and p38 pathways when it is activated in an NCAMindependent way.

The inhibitory effect of $\mathrm{C} 3 \mathrm{~d}$ is attenuated by ala substitutions in $\mathrm{C} 3 \mathrm{~d}$

It has previously been reported that two or more alanine substitutions in the $\mathrm{C} 3 \mathrm{~d}$ peptide block its ability to induce neurite outgrowth and to increase intracellular $\mathrm{Ca}^{2+}$ concentrations $[20,24]$. Furthermore, the capability of $\mathrm{C} 3 \mathrm{~d}$ to induce neurite outgrowth can be blocked by inhibitors of NCAM-induced intracellular signalling nec-
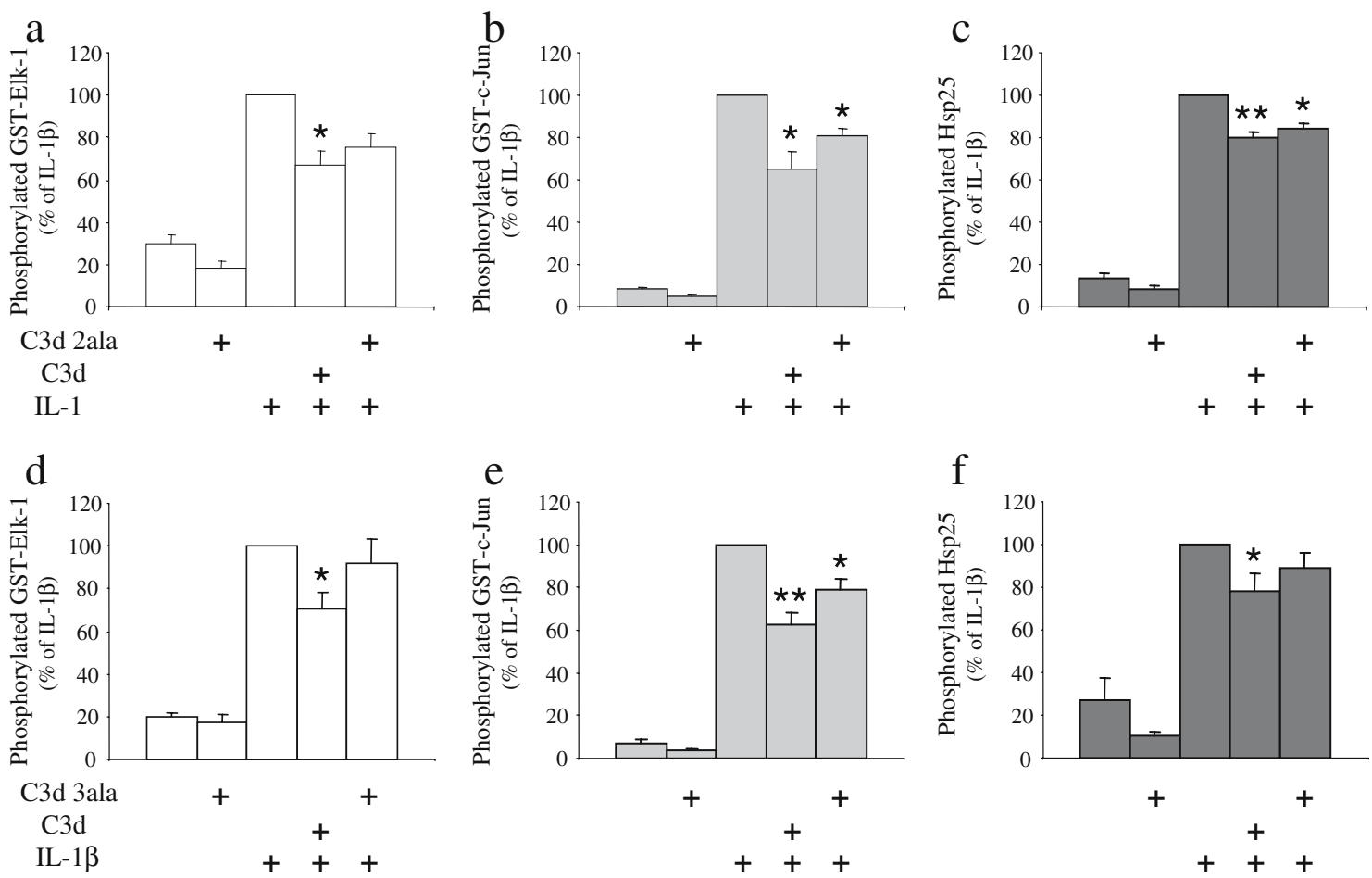

Fig. 6 The inhibitory effect of C3d on IL-1 $\beta$-induced MAPK activities is attenuated by ala substitutions. Cells were pre-exposed to $\mathrm{C} 3 \mathrm{~d}, \mathrm{C} 3 \mathrm{~d}$ 2ala $(\mathbf{a}-\mathbf{c})$, or C3d 3ala $(\mathbf{d}-\mathbf{f})(10 \mu \mathrm{mol} / \mathrm{l})$ for $30 \mathrm{~min}$ before exposure to IL-1 $\beta(160 \mathrm{pg} / \mathrm{ml})$ for $20 \mathrm{~min}$. MAPK activities were assessed by in vitro kinase assay. Bars represent means+SEM from four independent experiments. ${ }^{*} p<0.05,{ }^{* *} p<0.01$ vs IL- $1 \beta$ 


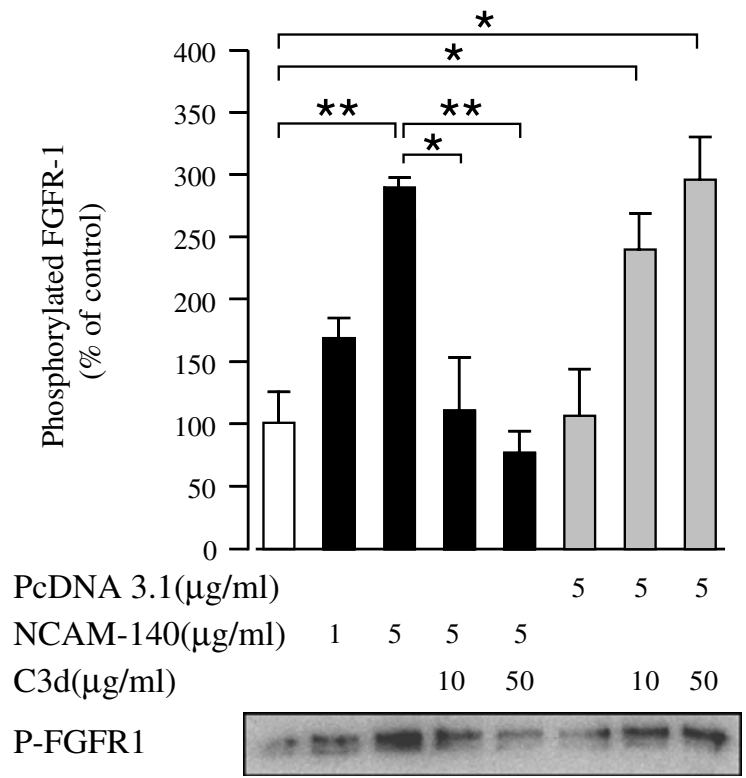

Fig. $7 \mathrm{C} 3 \mathrm{~d}$ inhibits NCAM-induced FGFR phosphorylation. Trex293 cells were transfected with NCAM-140 (1 or $5 \mu \mathrm{g} / \mathrm{ml})$ or control pcDNA $(5 \mu \mathrm{g} / \mathrm{ml})$ using Targetfect F2 reagent and exposed to $\mathrm{C} 3 \mathrm{~d}(10$ or $50 \mu \mathrm{g} / \mathrm{ml})$ for $30 \mathrm{~min}$. Phosphorylation of FGFR was investigated by western blotting using a phosphospecific antibody. Bars represent means+SEM from four independent experiments. $* p<0.05, * * p<0.01$

essary for NCAM-induced neurite outgrowth [20]. This indicates that the ability of the mutated peptides to induce intracellular NCAM-signalling is abolished. We investigated whether the inhibitory effect of $\mathrm{C} 3 \mathrm{~d}$ on IL-1 $\beta$ induced MAPK activities was also blocked when mutations were introduced in the $\mathrm{C} 3 \mathrm{~d}$ peptide. Two mutated C3d peptides were used: one with two alanine substitutions (C3d 2ala) (Fig. 6a-c) and one with three alanine substitutions (C3d 3ala) (Fig. 6d-f). The inhibitory effect of $\mathrm{C} 3 \mathrm{~d}$ on IL- $1 \beta$-mediated MAPK activities was attenuated, when mutations were introduced in the peptide. The order of inhibitory activity was $\mathrm{C} 3 \mathrm{~d} 3$ ala $<\mathrm{C} 3 \mathrm{~d} 2 \mathrm{ala}<\mathrm{C} 3 \mathrm{~d}$. These results indicate that the observed effect of C3d on IL$1 \beta$-signalling is independent of the activation of intracellular signalling, although this cannot be formally excluded. We speculate that the binding affinities of the peptides decrease with increasing number of mutations, suggesting that the inhibitory effect of $\mathrm{C} 3 \mathrm{~d}$ on $\mathrm{IL}-1 \beta$ signalling is dependent on binding to NCAM, which may antagonise NCAM-induced FGFR activation.

\section{C3d inhibits NCAM-140-induced phosphorylation of FGFR-1 in NCAM-140-transfected Trex293 cells}

To investigate the effect of C3d on NCAM-induced FGFR1 activity, we transfected Trex293 (which are not endogenously expressing NCAM) with NCAM-140 and measured phosphorylation of endogenous FGFR1. As seen in Fig. 7, NCAM-140 expression dose-dependently induced FGFR1 phosphorylation. When $\mathrm{C} 3 \mathrm{~d}$ was added this phosphorylation was blocked, indicating that $\mathrm{C} 3 \mathrm{~d}$ did indeed inhibit NCAM-induced FGFR activity.

We also investigated the effect of $\mathrm{C} 3 \mathrm{~d}$ when added to a cell system that does not express NCAM (control Trex293 cells transfected with pcDNA3.1 vector). Here, C3d induced phosphorylation of FGFR indicating that $\mathrm{C} 3 \mathrm{~d}$ in the absence of NCAM is able to activate FGFR1 either by binding to FGFR itself or another protein that is able to
Fig. 8 C3d does not affect basal or IL- $1 \beta$-induced I $\mathrm{B}$ degradation, NF-kB activity, or iNOS production. a Cells were preexposed to $\mathrm{C} 3 \mathrm{~d}(10 \mu \mathrm{mol} / \mathrm{l})$ for $30 \mathrm{~min}$ before exposure to IL-1 $\beta(160 \mathrm{pg} / \mathrm{ml})$, and IkB expression was assessed by western blotting after exposure to IL-1 $\beta$ for $5-20 \min (n=4$ except for C3d 50 min: $n=2$ ). b Cells transfected with an NF- $\mathrm{KB}$ reporter gene construct were preexposed to C3d ( 10 or $50 \mu \mathrm{mol} / \mathrm{l})$ for $30 \mathrm{~min}$ before exposure to IL$1 \beta(160 \mathrm{pg} / \mathrm{ml})$ for $6 \mathrm{~h}$. NF-kB promoter activity was measured as luciferase activity corrected for transfection efficiency (Renilla luciferase). Bars represent means+SEM from four experiments. c iNOS expression was assessed by western blotting after pre-exposure to $\mathrm{C} 3 \mathrm{~d}(10 \mu \mathrm{mol} / \mathrm{l})$ and exposure to IL-1 $\beta(160 \mathrm{pg} /$ $\mathrm{ml})$ for $6 \mathrm{~h}$. Bars represent means+SEM from four experiments. Representative blots are shown

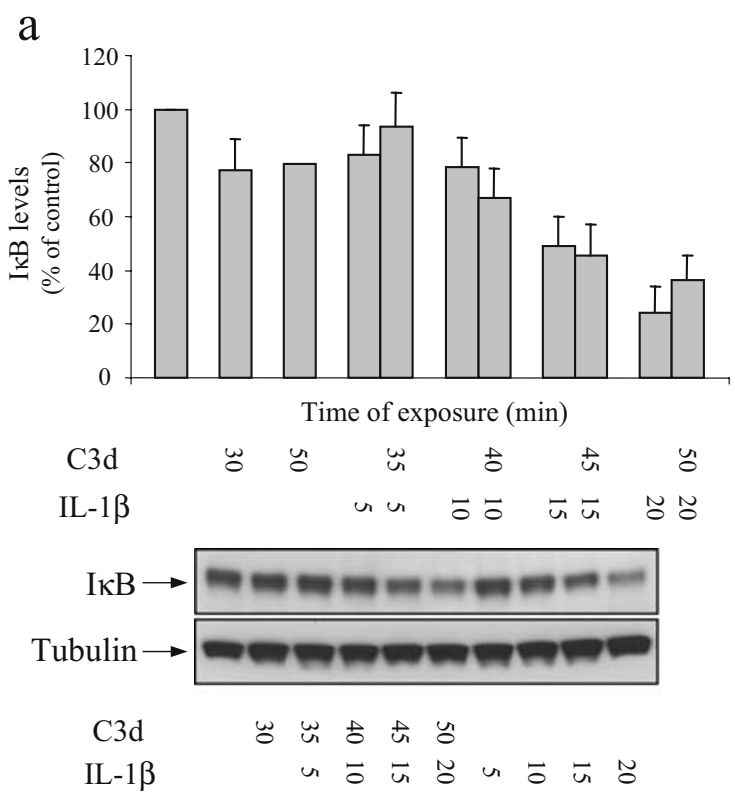

b

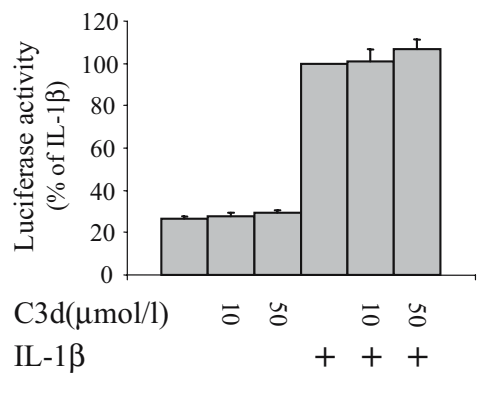

c

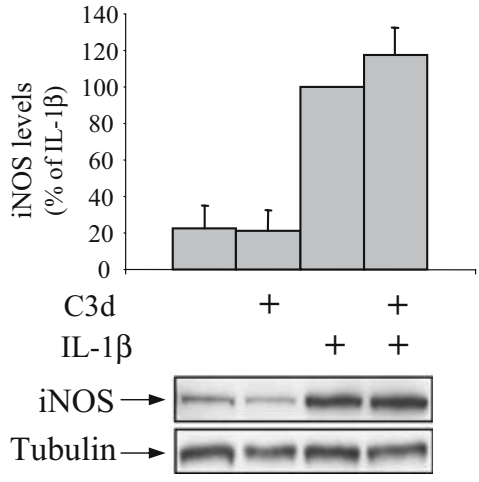


activate FGFR. However, in the presence of NCAM, C3d inhibited NCAM-induced FGFR phosphorylation.

C3d does not affect basal or IL-1 $\beta$-induced IкB

degradation, NF- $\mathrm{KB}$ activity, or iNOS expression

Activated NCAM has been shown to mediate I KB degradation and activation of NF- $\mathrm{KB}$ in neurons [17]. We therefore wished to investigate whether $\mathrm{C} 3 \mathrm{~d}$ affected basal and IL- $1 \beta$-induced NF-KB activation in INS-1E cells. The effect of $\mathrm{C} 3 \mathrm{~d}$ was examined on IKB degradation (Fig. 8a), NF-KB activity (Fig. 8b), and iNOS expression (Fig. 8c). In none of these experiments was NF- $\mathrm{kB}$ signalling activated by $\mathrm{C} 3 \mathrm{~d}$ and further IL- $1 \beta$-induced NF- $\mathrm{KB}$ signalling was not modulated by $\mathrm{C} 3 \mathrm{~d}$. Taken together these findings suggest that $\mathrm{C} 3 \mathrm{~d}$ inhibits a level downstream to the branching point between NF- $\mathrm{KB}$ and MAPK activation in the IL-1 $\beta$ pathway.

C3d, but not mutated C3d peptides, inhibits apoptosis induced by IL-1 $\beta$ plus IFN- $\gamma$

Finally, we investigated whether $\mathrm{C} 3 \mathrm{~d}$ affected apoptosis induced by IL- $1 \beta$ plus IFN- $\gamma$ measured as caspase-3 cleavage and release of nucleosomes to the cytosol. Cells were pre-exposed to $\mathrm{C} 3 \mathrm{~d}, \mathrm{C} 3 \mathrm{~d} 2 \mathrm{ala}$, or C3d 3ala $(50 \mu \mathrm{mol} / \mathrm{l})$ for $30 \mathrm{~min}$ before exposure to IL-1 $\beta(160 \mathrm{pg} / \mathrm{ml})$ and IFN- $\gamma(5 \mathrm{ng} / \mathrm{ml})$ for $24 \mathrm{~h}$. C3d had no effect on basal apoptosis but inhibited cytokine-induced caspase- 3 cleavage $(p<0.01)$ and release of nucleosomes (Fig. 9a,b). There was no effect of the mutated $\mathrm{C} 3 \mathrm{~d}$ peptides on basal or cytokine-induced release of nucleosomes (Fig. 9c). This indicates that $\mathrm{C} 3 \mathrm{~d}$ may have an anti-apoptotic action in beta cells and is at least partly able to reduce cytokine-induced apoptosis.

\section{Discussion}

Cytokines, in particular IL- $1 \beta$, have been implicated in the elimination of beta cells leading to type 1 diabetes [1]. An important event in IL-1 $\beta$ signalling leading to beta cell death is the activation of the MAPKs, in particular JNK [42]. Further understanding of the molecular mechanisms controlling cytokine-mediated MAPK activation may reveal novel drug targets for the treatment of type 1 diabetes and the protection of grafted islets. In neurons, signalling via NCAM/FGFR induces activation of ERK and is anti-apoptotic via activation of PI3K and Akt [18]. In this study, we investigated whether NCAM/FGFR signalling affected IL- $1 \beta$-induced signalling via the MAPKs and/ or NF-KB in beta cells using synthetic inhibitors of the FGFR1 (SU5402) and the Src-kinases (PP2) plus the synthetic NCAM binding peptide, C3d. We propose a model where NCAM-induced FGFR activity is required for cytokine-induced pro-apoptotic signalling to MAPK in beta cells. Thus, inhibition of FGFR with SU5402, but not a

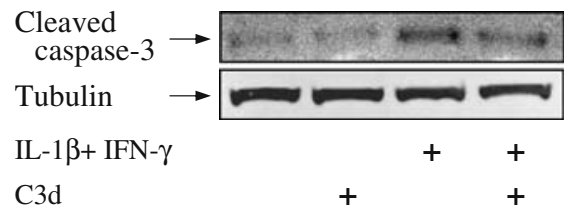

b
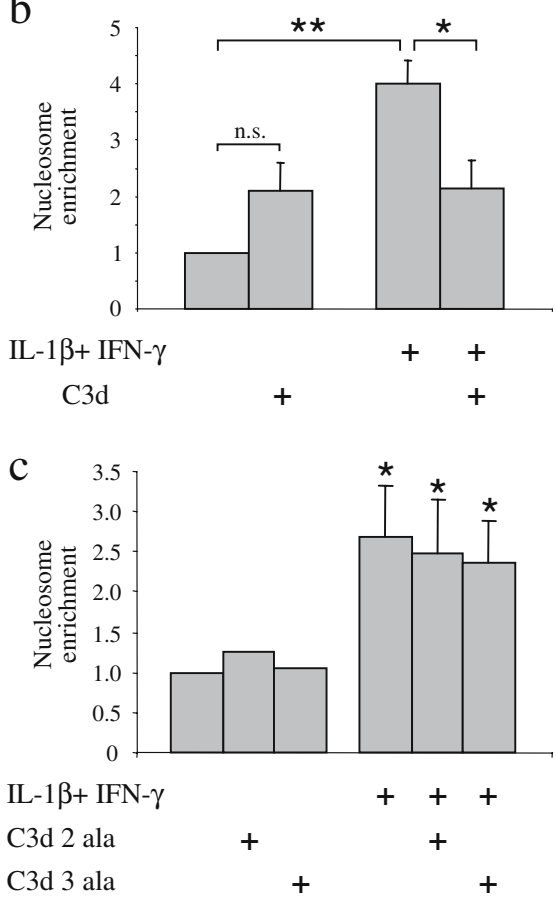

Fig. $9 \mathrm{C} 3 \mathrm{~d}$, but not $\mathrm{C} 3 \mathrm{~d}$ 2ala or C3d 3ala, inhibits apoptosis induced by IL- $1 \beta$ plus IFN- $\gamma$. Cells were pre-exposed to C3d $(50 \mu \mathrm{mol} / 1)$, C3d 2ala $(50 \mu \mathrm{mol} / 1)$ or C3d 3ala $(50 \mu \mathrm{mol} / \mathrm{l})$ for $30 \mathrm{~min}$ before exposure to IL-1 $\beta(160 \mathrm{pg} / \mathrm{ml})$ and IFN- $\gamma(5 \mathrm{ng} / \mathrm{ml})$ for $24 \mathrm{~h}$. a Cleaved caspase- 3 was assessed by western blotting; a representative blot is shown $(n=3)$. b, c Cytosolic nucleosomes were detected by Cell Death Detection ELISA ${ }^{\text {plus }}$. Bars represent means+SEM from six experiments (b) or four experiments (except for mutated C3d alone: $n=2$ ) (c). ${ }^{*} p<0.05,{ }^{* *} p<0.01$

inhibition of Src with PP2, decreased IL- $1 \beta$-induced MAPK activity. In addition, IL- $1 \beta$-induced MAPK activity and apoptosis were inhibited by exposure to $\mathrm{C} 3 \mathrm{~d}$. Based on our findings that (1) $\mathrm{C} 3 \mathrm{~d}$ mimics the effect of the FGFR inhibitor SU5402 and inhibits NCAM-induced FGFR phosphorylation and (2) in experiments with ala-substituted $\mathrm{C} 3 \mathrm{~d}$ peptides and $\mathrm{C} 3 \mathrm{~d}$ pre-coating indicating that the inhibitory effect of C3d is not caused by an agonistic effect of C3d on NCAM-mediated intracellular signalling, we suggest that NCAM/NCAM interactions are interrupted when C3d binds to NCAM. As a consequence, the NCAM/ FGFR interaction is disrupted and the NCAM-induced FGFR activation and agonistic cross-talk to IL-1 $\beta$ proapoptotic signalling is thereby abolished (Fig. 10).

It may be speculated that interference with NCAM may affect the intercellular relations in the islet-biosociology. However, NCAM seems to be less important for beta cell adhesion than for the adhesion of other islet endocrine 
Fig. 10 Model of C3d interactions with NCAM/FGFR signalling. a When NCAMNCAM trans dimers are formed between adjacent cells the FGFR is cis activated and downstream signalling induced facilitating IL-1 $\beta$ pro-apoptotic signalling to MAPK. b When cells are exposed to $\mathrm{C} 3 \mathrm{~d}, \mathrm{C} 3 \mathrm{~d}$ binds to the IgI domain of NCAM and mediates increased activity of an Src kinase. As a consequence of $\mathrm{C} 3 \mathrm{~d}$ binding, the NCAM-NCAM interactions are interrupted and the signalling through the FGFR, including the agonistic cross-talk to IL-1 $\beta$ pro-apoptotic signalling, is inhibited

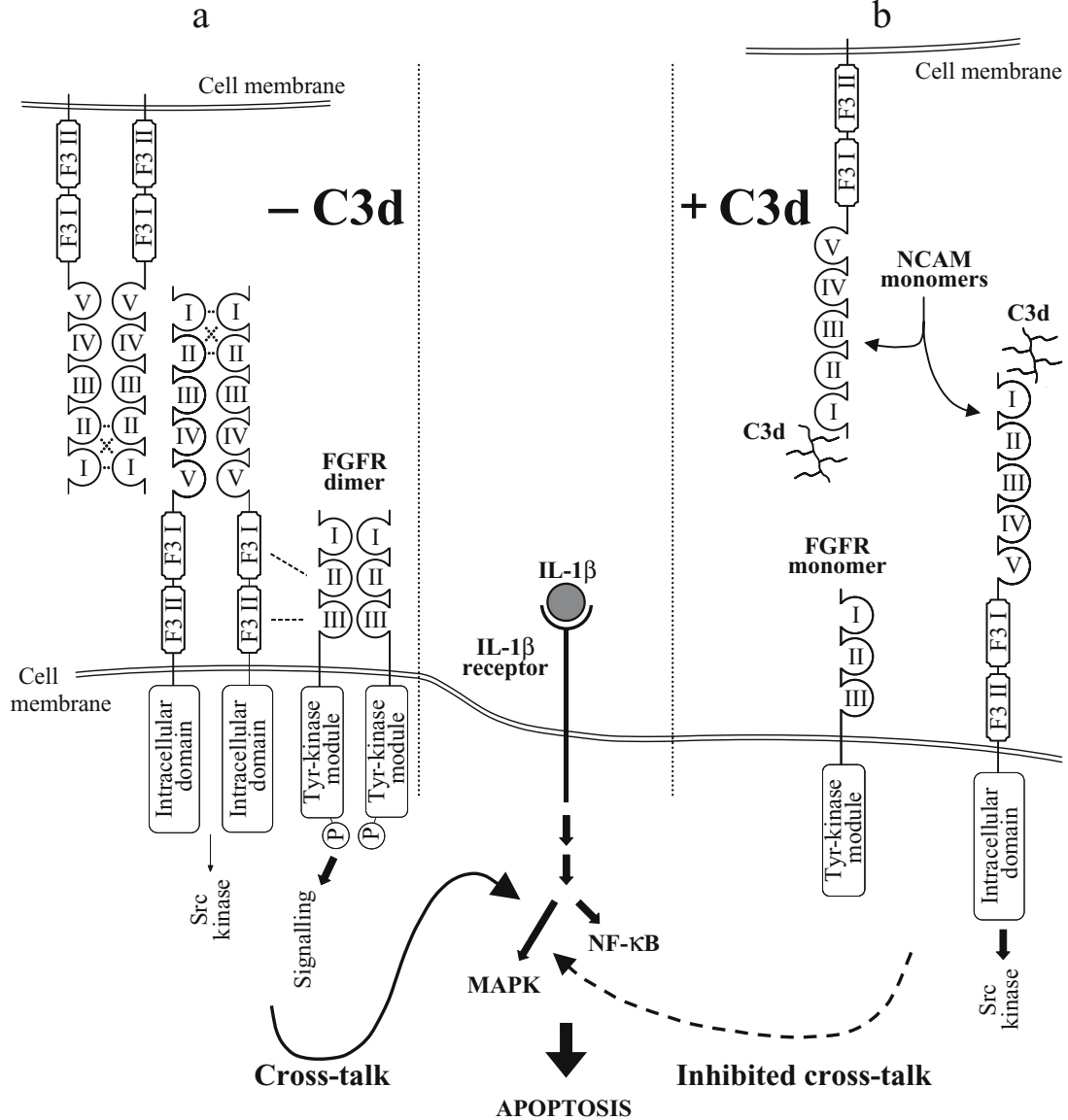

isoform able to recruit Fak and Fyn and be involved in neurite outgrowth whereas NCAM-180 primarily acts as a stabilising link between the cytoskeleton and the cell membrane $[19,44]$. Since the functions of the three NCAM isoforms are different it is most likely that the function of C3d is dependent on the combination of NCAM isoforms that is expressed by the cells.

Our observation that $\mathrm{C} 3 \mathrm{~d}$ activates FGFR phosphorylation in the absence of NCAM suggests that $\mathrm{C} 3 \mathrm{~d}$ is able to bind and activate the FGFR1 directly or via proteins other than NCAM. Further studies are needed to identify new targets of $\mathrm{C} 3 \mathrm{~d}$ but obvious candidates are the other members of the immunoglobulin superfamily, especially L1-cell adhesion molecule. However, it should be emphasised that $\mathrm{C} 3 \mathrm{~d}$ does not activate phosphorylation of FGFR when NCAM is present, suggesting that C3d has much higher affinity towards NCAM than to another target.

What are the molecular mechanisms by which NCAM/ FGFR signalling affects IL- $1 \beta$ signalling? In analogy to the effects of NCAM/FGFR signalling in neurons, an increase in the intracellular $\mathrm{Ca}^{2+}$ concentration could facilitate IL- $1 \beta$ signalling to the MAPKs in beta cells. Inhibition of $\mathrm{Ca}^{2+}$ influx has previously been shown to protect against cytokine-induced beta cell apoptosis, indicating that $\mathrm{Ca}^{2+}$ plays a role in cytokine signalling [35, 45-47]. Further establishing $\mathrm{Ca}^{2+}$ as the link is our observation that $\mathrm{Ca}^{2+}$ does not seem to be involved in IL-1 $\beta$-induced NF- $K B$ activation [47] in accordance with the lack of effect of C3d are not fully understood, NCAM-140 seems to be the only signalling [23]. A possible explanation for specific differences in the $\mathrm{C} 3 \mathrm{~d}$ response between beta cells and neurons might be that beta cells exclusively express NCAM-140 whereas neurons express all three isoforms.
Even though the functions of the different NCAM isoforms 
on IL-1 $\beta$-induced NF-kB activation. Further studies are needed to examine this hypothesis.

In conclusion, this study suggests that IL- $1 \beta$-induced pro-apoptotic MAPK activation in beta cells requires NCAM/FGFR signalling. A novel role of $\mathrm{C} 3 \mathrm{~d}$ as an inhibitor of NCAM-induced FGFR phosphorylation is proposed and $\mathrm{C} 3 \mathrm{~d}$ was found to inhibit IL- $1 \beta$-induced MAPK activity and apoptosis. Taken together, these results are novel in describing how IL-1 $\beta$ pro-apoptotic signalling in beta cells can be modified by adhesion molecule signalling and can provide new potential targets for the development of treatments for type 1 diabetes and islet graft failure.

Acknowledgements A.-S. Hillesø, H. Foght, A. H. Schram, and M. Lotfi are thanked for excellent technical help. This work was partly supported by grants from the University of Copenhagen Researchpriority-area BioCampus, the Lundbeck foundation, the Danish Cancer Society, the Danish Medical Research Council and Novo Nordisk.

Duality of interest V. Berezin and E. Bock are minority shareholders in ENKAM Pharmaceuticals, which holds the patent for the C3d peptide.

\section{References}

1. Mandrup-Poulsen T (1996) The role of interleukin-1 in the pathogenesis of IDDM. Diabetologia 39:1005-1029

2. Eizirik DL, Mandrup-Poulsen T (2001) A choice of death - the signal-transduction of immune-mediated beta-cell apoptosis. Diabetologia 44:2115-2133

3. Hoorens A, Stange G, Pavlovic D, Pipeleers D (2001) Distinction between interleukin-1-induced necrosis and apoptosis of islet cells. Diabetes 50:551-557

4. Delaney CA, Pavlovic D, Hoorens A, Pipeleers DG, Eizirik DL (1997) Cytokines induce deoxyribonucleic acid strand breaks and apoptosis in human pancreatic islet cells. Endocrinology 138:2610-2614

5. Larsen CM, Wadt KA, Juhl LF et al (1998) Interleukin-1betainduced rat pancreatic islet nitric oxide synthesis requires both the p38 and extracellular signal-regulated kinase 1/2 mitogenactivated protein kinases. J Biol Chem 273:15294-15300

6. Ammendrup A, Maillard A, Nielsen K et al (2000) The c-Jun amino-terminal kinase pathway is preferentially activated by interleukin-1 and controls apoptosis in differentiating pancreatic beta-cells. Diabetes 49:1468-1476

7. Moller CJ, Christgau S, Williamson MR et al (1992) Differential expression of neural cell adhesion molecule and cadherins in pancreatic islets, glucagonomas, and insulinomas. Mol Endocrinol 6:1332-1342

8. Walmod PS, Kolkova K, Berezin V, Bock E (2004) Zippers make signals: NCAM-mediated molecular interactions and signal transduction. Neurochem Res 29:2015-2035

9. Ronn LCB, Hartz BP, Bock E (1998) The neural cell adhesion molecule (NCAM) in development and plasticity of the nervous system. Exp Gerontol 33:853-864

10. Ronn LCB, Berezin V, Bock E (2000) The neural cell adhesion molecule in synaptic plasticity and ageing. Int J Dev Neurosci 18:193-199

11. Kolkova K, Pedersen N, Berezin V, Bock E (2000) Identification of an amino acid sequence motif in the cytoplasmic domain of the NCAM-140 $\mathrm{kDa}$ isoform essential for its neuritogenic activity. J Neurochem 75:1274-1282
12. Kiselyov VV, Soroka V, Berezin V, Bock E (2005) Structural biology of NCAM homophilic binding and activation of FGFR. J Neurochem 94:1169-1179

13. Soroka V, Kolkova K, Kastrup JS et al (2003) Structure and interactions of NCAM Ig1-2-3 suggest a novel zipper mechanism for homophilic adhesion. Structure (Cambridge) 11:1291-1301

14. Williams EJ, Furness J, Walsh FS, Doherty P (1994) Activation of the FGF receptor underlies neurite outgrowth stimulated by L1, N-CAM, and N-cadherin. Neuron 13:583-594

15. Kiselyov VV, Skladchikova G, Hinsby AM et al (2003) Structural basis for a direct interaction between FGFR1 and NCAM and evidence for a regulatory role of ATP. Structure (Cambridge) 11:691-701

16. Jessen U, Novitskaya V, Pedersen N, Serup P, Berezin V, Bock E (2001) The transcription factors CREB and c-Fos play key roles in NCAM-mediated neuritogenesis in PC12-E2 cells. J Neurochem 79:1149-1160

17. Krushel LA, Cunningham BA, Edelman GM, Crossin KL (1999) NF-kappaB activity is induced by neural cell adhesion molecule binding to neurons and astrocytes. J Biol Chem 274:2432-2439

18. Ditlevsen DK, Kohler LB, Pedersen MV et al (2003) The role of phosphatidylinositol 3-kinase in neural cell adhesion moleculemediated neuronal differentiation and survival. J Neurochem $84: 546-556$

19. Schmid RS, Graff RD, Schaller MD et al (1999) NCAM stimulates the Ras-MAPK pathway and CREB phosphorylation in neuronal cells. J Neurobiol 38:542-558

20. Ronn LC, Olsen M, Ostergaard S et al (1999) Identification of a neuritogenic ligand of the neural cell adhesion molecule using a combinatorial library of synthetic peptides. Nat Biotechnol 17:1000-1005

21. Berezin V, Bock E (2003) NCAM mimetic peptidespharmacological and therapeutic potential. J Mol Neurosci 22:33-39

22. Soroka V, Kiryushko D, Novitskaya V et al (2002) Induction of neuronal differentiation by a peptide corresponding to the homophilic binding site of the second Ig module of the neural cell adhesion molecule. J Biol Chem 277:24676-24683

23. Ronn LC, Doherty P, Holm A, Berezin V, Bock E (2000) Neurite outgrowth induced by a synthetic peptide ligand of neural cell adhesion molecule requires fibroblast growth factor receptor activation. J Neurochem 75:665-671

24. Ronn LCB, Dissing S, Holm A, Berezin V, Bock E (2002) Increased intracellular calcium is required for neurite outgrowth induced by a synthetic peptide ligand of NCAM. FEBS Lett 518:60-66

25. Langley OK, Aletsee-Ufrecht MC, Grant NJ, Gratzl M (1989) Expression of the neural cell adhesion molecule NCAM in endocrine cells. J Histochem Cytochem 37:781-791

26. Esni F, Taljedal IB, Perl AK, Cremer H, Christofori G, Semb H (1999) Neural cell adhesion molecule (N-CAM) is required for cell type segregation and normal ultrastructure in pancreatic islets. J Cell Biol 144:325-337

27. Perl AK, Dahl U, Wilgenbus P, Cremer H, Semb H, Christofori G (1999) Reduced expression of neural cell adhesion molecule induces metastatic dissemination of pancreatic beta tumor cells. Nat Med 5:286-291

28. Aletsee-Ufrecht MC, Langley OK, Gratzl M (1990) NCAM expression in endocrine cells. Acta Histochem Suppl 38:45-50

29. Rouiller DG, Cirulli V, Halban PA (1990) Differences in aggregation properties and levels of the neural cell adhesion molecule (NCAM) between islet cell types. Exp Cell Res 191:305-312

30. Bernard-Kargar C, Kassis N, Berthault MF, Pralong W, Ktorza A (2001) Sialylated form of the neural cell adhesion molecule (NCAM): a new tool for the identification and sorting of betacell subpopulations with different functional activity. Diabetes 50(Suppl 1):S125-S130 
31. Ou D, Metzger DL, Wang X, Pozzilli P, Tingle AJ (2002) Betacell antigen-specific CD56(+) NKT cells from type 1 diabetic patients: autoaggressive effector T cells damage human CD56 $(+)$ beta cells by HLA-restricted and non-HLA-restricted pathways. Hum Immunol 63:256-270

32. Cavallaro U, Niedermeyer J, Fuxa M, Christofori G (2001) NCAM modulates tumour-cell adhesion to matrix by inducing FGF-receptor signalling. Nat Cell Biol 3:650-657

33. Saldeen J, Lee JC, Welsh N (2001) Role of p38 mitogenactivated protein kinase (p38 MAPK) in cytokine-induced rat islet cell apoptosis. Biochem Pharmacol 61:1561-1569

34. Pavlovic D, Andersen NA, Mandrup-Poulsen T, Eizirik DL (2000) Activation of extracellular signal-regulated kinase (ERK) $1 / 2$ contributes to cytokine-induced apoptosis in purified rat pancreatic beta-cells. Eur Cytokine Netw 11:267-274

35. Maedler K, Størling J, Sturis J et al (2004) Glucose- and interleukin- $1 \beta$-induced $\beta$-cell apoptosis requires $\mathrm{Ca}^{2+}$ influx and extracellular signal-regulated kinase (ERK) $1 / 2$ activation and is prevented by a sulfonylurea receptor 1/inwardly rectifying $\mathrm{K}^{+}$channel 6.2 (SUR/Kir6.2) selective potassium channel opener in human islet. Diabetes 53:1706-1713

36. Aarnes M, Schonberg S, Grill V (2002) Fatty acids potentiate interleukin-1 beta toxicity in the beta-cell line INS-1E. Biochem Biophys Res Commun 296:189-193

37. Carpenter L, Cordery D, Biden TJ (2002) Inhibition of protein kinase $\mathrm{C}$ delta protects rat INS-1 cells against interleukin-1 beta and streptozotocin-induced apoptosis. Diabetes 51:317-324

38. Cardozo AK, Heimberg H, Heremans Y et al (2001) A comprehensive analysis of cytokine-induced and nuclear factorkappa B-dependent genes in primary rat pancreatic beta-cells. J Biol Chem 276:48879-48886
39. Aikin R, Maysinger D, Rosenberg L (2004) Cross-talk between phosphatidylinositol 3-kinase/AKT and c-Jun $\mathrm{NH}_{2}$-terminal kinase mediates survival of isolated human islets. Endocrinology 145:4522-4531

40. Kasper C, Stahlhut M, Berezin V et al (1996) Functional characterization of NCAM fibronectin type III domains: demonstration of modulatory effects of the proline-rich sequence encoded by alternatively spliced exons a and AAG. J Neurosci Res 46:173-186

41. Beggs HE, Baragona SC, Hemperly JJ, Maness PF (1997) NCAM140 interacts with the focal adhesion kinase p125(fak) and the SRC-related tyrosine kinase p59(fyn). J Biol Chem 272:8310-8319

42. Donath MY, Størling J, Maedler K, Mandrup-Poulsen T (2003) Inflammatory mediators and islet beta-cell failure: a link between type 1 and type 2 diabetes. J Mol Med 81:455-470

43. Cirulli V, Baetens D, Rutishauser U, Halban PA, Orci L, Rouiller DG (1994) Expression of neural cell adhesion molecule (N-CAM) in rat islets and its role in islet cell type segregation. J Cell Sci 107:1429-1436

44. Buttner B, Reutter W, Horstkorte R (2004) Cytoplasmic domain of NCAM 180 reduces NCAM-mediated neurite outgrowth. J Neurosci Res 75:854-860

45. Wang L, Bhattacharjee A, Zuo Z et al (1999) A low voltageactivated $\mathrm{Ca}^{2+}$ current mediates cytokine-induced pancreatic beta-cell death. Endocrinology 140:1200-1204

46. Zaitsev SV, Appelskog IB, Kapelioukh IL et al (2001) Imidazoline compounds protect against interleukin 1betainduced beta-cell apoptosis. Diabetes 50:S70-S76

47. Størling J, Zaitsev SV, Kapelioukh IL et al (2005) Calcium has a permissive role in interleukin-1 $\beta$-induced c-Jun n-terminal kinase activation in insulin-secreting cells. Endocrinology $146: 3026-3036$ 